\title{
Modeling increased riverine nitrogen export: Source tracking and integrated watershed-coast management
}

\author{
Dan Yu ${ }^{\mathrm{a}}$, Weijin Yan ${ }^{\mathrm{b}}$, Nengwang Chen ${ }^{\mathrm{a}, *}$, Benrong Peng ${ }^{\mathrm{a}}$, Huasheng Hong ${ }^{\mathrm{a}}$, Guihua Zhuo ${ }^{\mathrm{c}}$

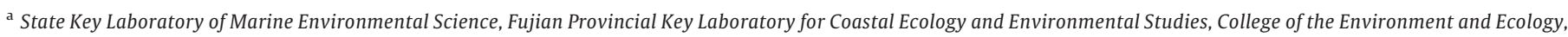 \\ Xiamen University, Xiamen 361102, China \\ b Institute of Geographic Sciences and Natural Resources Research, Chinese Academy of Sciences, Beijing 100101, China

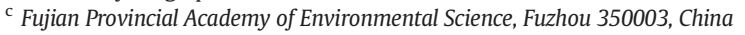

\section{A R T I C L E I N F O}

\section{Article history:}

Received 15 August 2015

Received in revised form 14 October 2015

Accepted 16 October 2015

Available online 27 October 2015

\section{Keywords:}

Dissolved inorganic nitrogen

Eutrophication

Coastal management

Jiulong River

\begin{abstract}
A B S T R A C T
The global NEWS model was calibrated and then used to quantify the long term trend of dissolved inorganic nitrogen (DIN) export from two tributaries of Jiulong River (SE China). Anthropogenic N inputs contributed $61-92 \%$ of river DIN yield which increased from 337 in 1980s to $1662 \mathrm{~kg} \mathrm{~N} \mathrm{~km}^{-2} \mathrm{yr}^{-1}$ in 2000s for the North River, and from 653 to $3097 \mathrm{~kg} \mathrm{~N} \mathrm{~km}^{-2} \mathrm{yr}^{-1}$ for the West River. North River and West River contributed 55\% and $45 \%$ respectively of DIN loading to the estuary. Rapid development and poor management driven by national policies were responsible for increasing riverine $\mathrm{N}$ export. Scenario analysis and source tracking suggest that reductions of anthropogenic N inputs of at least 30\% in the North River (emphasis on fertilizer and manure) and $50 \%$ in the West River (emphasis on fertilizer) could significantly improve water quality and mitigate eutrophication in both river and coastal waters.
\end{abstract}

(c) 2015 Elsevier Ltd. All rights reserved.

\section{Introduction}

Over the past few decades, estuaries and coastal marine ecosystems have been heavily loaded with riverine nutrients (e.g. $\mathrm{N}$ and $\mathrm{P}$ ) as a result of anthropogenic activities (Howarth, 2008; Peñuelas et al., 2013; Turner and Rabalais, 1994). Increasing watershed nutrient export has caused eutrophication, harmful algal blooms and other negative environmental effects in coastal waters around the world (Anderson et al., 2008; Billen and Garnier, 2007; Davidson et al., 2014; Paerl et al., 2011; Smith et al., 1999). Riverine export of dissolved nutrients (especially $\mathrm{N}$ ) from Asian watersheds has been predicted to continue to increase through 2030 (Seitzinger et al., 2010). Anthropogenic N inputs from agricultural production, livestock and poultry farming and sewage discharge affect the magnitude and trajectory of riverine dissolved inorganic N (DIN). Nutrient over-enrichment has become a critical issue in Chinese estuaries and coastal waters due to rapid socio-economic growth and poor nutrient management (Chen and Hong, 2012; Huang and Hong, 2010; Li et al., 2014; Yin and Harrison, 2008). Modeling of long-term trends of DIN export provides scientific understanding of the watershed-coast relationship (Sattar et al., 2014), and tracking key sources assists in identifying critical factors to reduce $\mathrm{N}$ pollution loading and in mitigating eutrophication in riverine and coastal aquatic ecosystems.

\footnotetext{
* Corresponding author at: College of the Environment and Ecology, Xiamen University, Xiamen 361102, China.

E-mail address: nwchen@xmu.edu.cn (N. Chen).
}

A number of models have been developed to estimate riverine $\mathrm{N}$ export from watersheds. For example, INCA (the Integrated Catchment Model of Nitrogen) simulates $\mathrm{N}$ transport through terrestrial systems into rivers based on detailed hydrological and biochemical process equations (Whitehead et al., 1998); SWAT (the Soil and Water Assessment Tool) simulates nutrients yield in surface runoff and identifies critical source area (CSA) (Arnold et al., 1998); and SPARROW (SPAtially Referenced Regressions On Watershed attributes) is a hybrid processbased statistical model which quantifies pollutant source and transport by linking watershed characteristics and in-stream water quality (Smith et al., 1997). Implementing these models requires detailed, high quality input data which is often not available for large watersheds. Global NEWS-2 (Nutrient Export from WaterSheds) is a spatially explicit watershed scale model (Mayorga et al., 2010) which has been applied at the global (Dumont et al., 2005; Mayorga et al., 2010; Seitzinger et al., 2010) and regional scales (Bowes et al., 2005; Qu and Kroeze, 2010; Suwarno et al., 2013). Global NEWS-2 is an ideal tool for management purposes in data-poor regions such as China's coastal watersheds because it requires mainly social-economic input data and simple model parameters. The model has been applied to large Chinese rivers including the Pearl River (Strokal et al., 2015) and the Yangtze River (Yan et al., 2010). However, how the model assists in controlling nutrient pollution is still under studied. Nutrient management should address the river-estuary-bay continuum within an integrated framework (Chen and Hong, 2012). Typically, coastal and estuary waters receive $\mathrm{N}$ loading from various tributaries. To mitigate eutrophication in an efficient way, modeling the long-term trend of $\mathrm{N}$ export by source 
at the sub-watershed scale is essential to help decision makers to prioritize pollution management strategies.

In this study, we applied the Global NEWS-DIN model to the Jiulong River watershed, a meso-scale $\left(14741 \mathrm{~km}^{2}\right)$ agricultural watershed in southeast China. Two major tributaries (North River and West River) discharging fresh water into the estuary and then Xiamen Bay. The North River contributes two-thirds of water discharge and is profoundly influenced by livestock breeding, while the West River has a smaller catchment area with widespread cultivation of cash crops. Riverine inputs dominate $\mathrm{N}$ loading in the Jiulong River estuary and Xiamen Bay, which have suffered undesirable algal blooms since the mid-1990s when nutrient enrichment began (Chen et al., 2013). Due to their distinct watershed characteristics and economic development patterns, these two tributaries provide an ideal opportunity for comparison by modeling of the increased $\mathrm{N}$ export. Based on an extensive database (1980-2010) and previous research on N biogeochemistry in the Jiulong River watershed, model parameters were calibrated and modified by tributary and then used to estimate $\mathrm{N}$ inputs and river DIN yield. This study aims to quantify the long term (1980-2010) trend of DIN export from watershed to coast and to determine the relative contribution of the two tributaries, and the contributions of various $\mathrm{N}$ sources within each tributary. Scenario analysis was conducted to provide a future management strategy (how much and where to reduce $\mathrm{N}$ input) to meet national water quality criteria as well as mitigate eutrophication in coastal waters.

\section{Materials and methods}

\subsection{Study area}

The Jiulong River flows through an agricultural river watershed in southeast China, with a subtropical climate and annual precipitation ranging from 1400 to $1800 \mathrm{~mm}$. Two main tributaries (North River and West River) converge at the head of the estuary and discharge water to Xiamen Bay (Fig. 1). The North River is the largest tributary (annual discharge 127-437 $\mathrm{m}^{3} \mathrm{~s}^{-1}$ ), contributing two-thirds of the total water discharge. The North River is $272 \mathrm{~km}$ long and has a catchment area of $9562 \mathrm{~km}^{2}$, encompassing four major cities/counties (Longyan, Zhangping, Changtai, and Hua'an) and part of Anxi County and Zhangzhou City. Over 60\% of this watershed is covered by forest and upland orchard. In its upper area (Longyan City), there is a large population of 0.5 million as well as a large number of livestock (mainly pigs), resulting in excessive nutrient discharge from human and animal wastes (Chen et al., 2013). For the purposes of hydropower generation and irrigation, more than 60 dams (including six large dams along the main stem) have been constructed since the late 1990s. Jiangdong Reservoir in the lower river is impounded by a dike adjacent to the estuary, and provides over $80 \%$ of drinking water to Xiamen City. The West River has a shorter length of $172 \mathrm{~km}$, a drainage area of $3938 \mathrm{~km}^{2}$, and annual water discharge of 68-209 $\mathrm{m}^{3} \mathrm{~s}^{-1}$, and the drainage area encompasses four major cities/counties (Pinghe, Nanjing, the majority of Zhangzhou

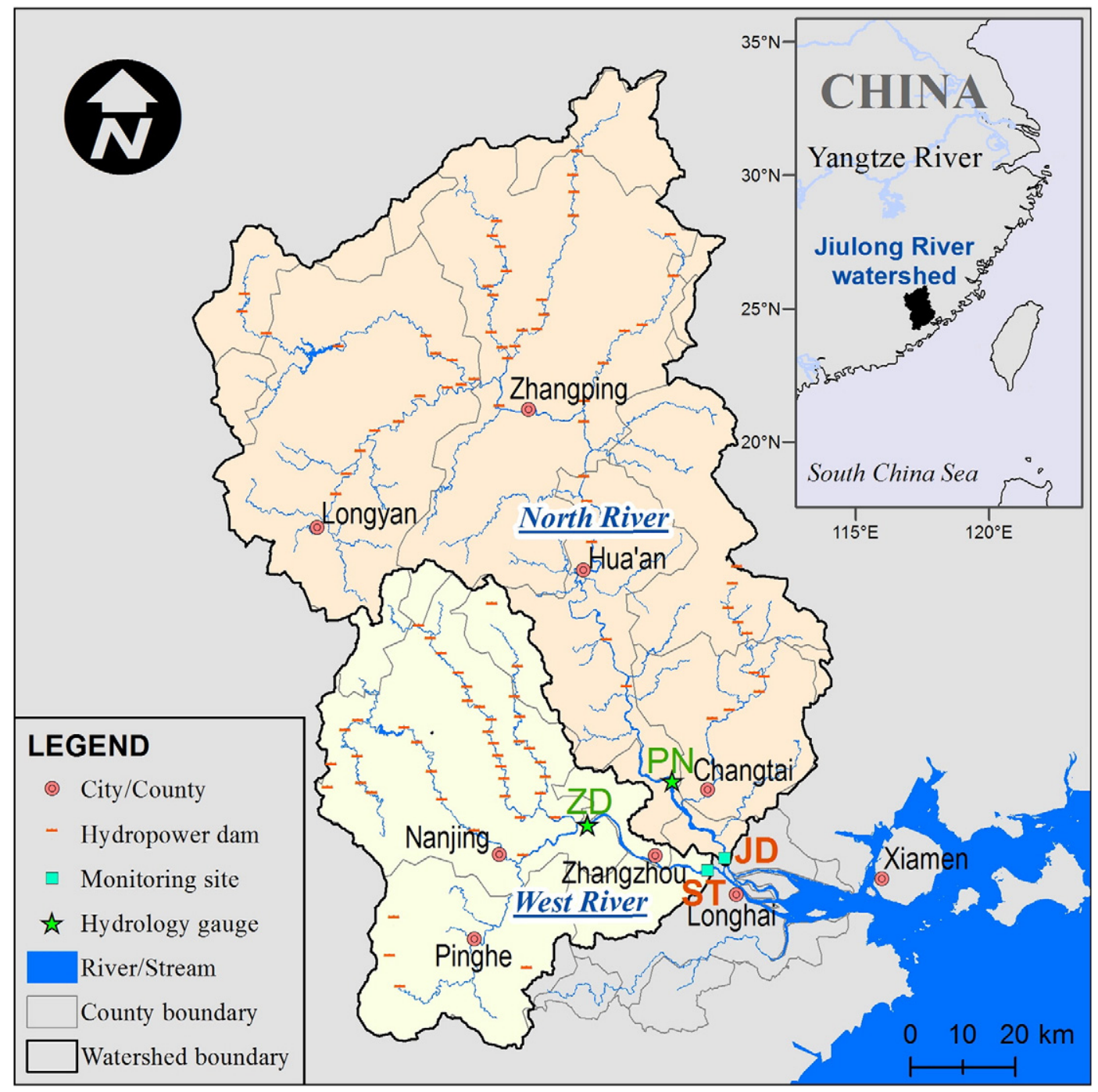

Fig. 1. Map of study area showing two tributaries in the Jiulong River watershed, Southeast China. 
and part of Longhai). In contrast to the North River, the West River watershed contains larger areas of cash crops (including Citrus maxima, Dimocarpus longan and several types of vegetables), particularly in the upper and middle tributary areas (i.e., Pinghe County, Nanjing County and suburban Zhangzhou). Excessive chemical fertilizer application has resulted in considerable diffuse $\mathrm{N}$ loss to the river channel via field runoff and baseflow (Chen and Hong, 2011). The West River also receives a large quantity of human wastes because the river bank is densely populated, especially in the lower area (Zhangzhou City, where a secondary sewage treatment plant achieves only minor $\mathrm{N}$ reduction). Only half as many dams have been constructed in the West River compared to the North River, and most dams are relatively small and located in sub-tributaries (Fig.1).

\subsection{Data collection and pre-treatment}

Model input data were prepared for the North River and the West River separately. Socio-economic data required by the model were obtained at the county level from statistical yearbooks. For those counties across watershed boundary, data were allocated into two watersheds based on the land use area of each county within the watershed boundary.

In order to test the model, annual mean concentration of DIN (sum of nitrate, nitrite and ammonium N) from the two water quality monitoring sites furthest downstream (JD and ST, see Fig. 1) was obtained from local government data. Annual water discharge at two hydrological gauges (PN in the North River and ZD in the West River) was extrapolated to the water quality sites (JD and ST) using a catchment area corrected coefficient of 1.08 and 1.05 , respectively. Observed DIN yield was calculated as the product of annual mean DIN concentration and river discharge.

\subsection{Model structure and parameters determination}

Descriptions of all the parameters used in the present model are given in Table 1. The Global NEWS-DIN model was formulated as shown in Eq. (1) (Dumont et al., 2005; Mayorga et al., 2010).

$\mathrm{DIN}_{\text {yield-mod }}=\mathrm{FE}_{\mathrm{riv}} \cdot\left(\mathrm{DIN}_{\mathrm{sew}}+\mathrm{FE}_{\mathrm{ws}} \cdot \mathrm{TN}_{\mathrm{diff}}\right)$

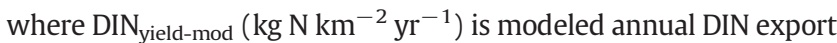
from watershed into coastal system; $\mathrm{FE}_{\mathrm{riv}}(0-1)$ is a river export fraction representing the fraction of total DIN inputs to the river that is exported

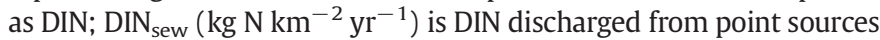

(mainly sewage) to rivers; $\mathrm{FE}_{\mathrm{ws}}(0-1)$ is a watershed export fraction representing the fraction of total nitrogen (TN) from diffuse sources in the watershed that leaches to rivers as DIN; $\operatorname{TN}_{\text {diff }}\left(\mathrm{kg} \mathrm{N} \mathrm{km}^{-2} \mathrm{yr}^{-1}\right)$ is net total $\mathrm{N}$ input from diffuse sources transported and transformed through watershed soils and sediments. Almost all watershed-scale $\mathrm{N}$ input and export terms (including DIN $_{\text {yield }}$, DIN $_{\text {sew }}$, and $\mathrm{TN}_{\text {diff }}$ ) per year of the North River and the West River were normalized by watershed areas at JD and ST, in units of $\mathrm{kg} \mathrm{N} \mathrm{km}^{-2} \mathrm{yr}^{-1}$, respectively. Exceptions will be noted below.

The individual contributions of sewage input and each diffuse source to DIN yield were calculated by isolating the respective terms in Eq. (1) (Mayorga et al., 2010).

\subsubsection{Point sources ( $\left.D I N_{\text {sew }}\right)$}

The Global NEWS model has previously applied an indirect approach for estimating the total $\mathrm{N}$ discharged from sewage point sources $\left(\mathrm{TN}_{\mathrm{sew}}\right.$, $\mathrm{kg} \mathrm{N} \mathrm{km}^{-2} \mathrm{yr}^{-1}$ ), as described by Dumont et al. (2005) and shown in Eq. (2).

$\mathrm{TN}_{\text {sew }}=\left(1-\mathrm{F}_{\mathrm{N}}\right) \cdot \mathrm{I} \cdot\left(\mathrm{H} \cdot \mathrm{E}_{\mathrm{N}}\right)$

where $\mathrm{TN}_{\text {sew }}\left(\mathrm{kg} \mathrm{N} \mathrm{km}^{-2} \mathrm{yr}^{-1}\right)$ is total $\mathrm{N}$ input into rivers from point sources; $\mathrm{E}_{\mathrm{N}}\left(\mathrm{kg} \mathrm{N}\right.$ ind. $\left.{ }^{-1} \mathrm{yr}^{-1}\right)$ is annual $\mathrm{N}$ emission as human waste per capita, estimated by a function of GDP Purchasing Power Parity $\left(\mathrm{GDP}_{\mathrm{ppp}}\right.$ ) (Van Drecht et al., 2009); $\mathrm{H}$ (ind. $\mathrm{km}^{-2}$ ) is population density, I (\%) is the fraction of the population that is connected to a sewage system, and $F_{N}$ is the fraction of TN in sewage influent that is removed by wastewater treatment. For details of parameters determination see a previous study on the Changjiang River (Yan et al., 2010). A direct approach is to define $\mathrm{TN}_{\text {sew }}$ as the product of wastewater discharge $\left(\mathrm{kg} \mathrm{yr}^{-1}\right)$ and $\mathrm{N}$ concentration in sewage effluents, and calculate $\mathrm{TN}_{\text {sew }}$ separately for industrial and domestic effluents, which has been shown to give DIN yield values closer to the real value (Yan et al., 2010). However, as data for industrial effluents in the present study were not available, we used the indirect approach.

DIN $_{\text {sew }}$ was then calculated by multiplying $\mathrm{TN}_{\text {sew }}$ by an empirical estimated fraction of TN that is DIN in sewage effluents (Dumont et al., 2005), as shown in Eq. (3).

$\mathrm{DIN}_{\text {sew }}=\mathrm{TN}_{\text {sew }} \cdot\left[0.485+\frac{\mathrm{F}_{\mathrm{N}}}{\max \left(\mathrm{F}_{\mathrm{N}}\right)} \cdot 0.255\right]$

where $\max \left(F_{N}\right)$ is the highest value of all countries for which $F_{N}$ is known (=0.8 in Finland), 0.485 is an estimated fraction of TN that is

Table 1

Parameters used in the present model.

\begin{tabular}{|c|c|c|c|}
\hline Model parts & Parameters & Units & Parameter description \\
\hline \multirow[t]{4}{*}{ Hydrology coefficient } & runoff & $\mathrm{m} \mathrm{yr}^{-1}$ & Water runoff (calculated as discharge at selected site divided by its drainage area) \\
\hline & $Q_{\text {rem }}$ & $0-1$ & Fraction of water removed from the river for consumption \\
\hline & $\mathrm{D}_{\mathrm{N}}$ & $0-1$ & Fraction of $\mathrm{N}$ retained by reservoirs \\
\hline & $\mathrm{L}_{\mathrm{N}}$ & $0-1$ & Fraction of $\mathrm{N}$ removed from streams by denitrification (not in reservoirs) \\
\hline \multirow[t]{6}{*}{ Point sources } & $\mathrm{GDP}_{\mathrm{ppp}}$ & U.S. \$ ind. ${ }^{-1}$ & Gross Domestic Product Purchasing-Power Parity (used in the NEWS point source model). \\
\hline & $\mathrm{F}_{\mathrm{N}}$ & $0-1$ & Fraction of TN in sewage influent that is removed by wastewater treatment \\
\hline & $\mathrm{E}_{\mathrm{N}}$ & $\mathrm{kg} \mathrm{N}$ ind..$^{-1} \mathrm{yr}^{-1}$ & Annual N emission as human waste per capita \\
\hline & I & $\%$ & $\%$ of population connected to sewage system (from \%urban population in the watershed) \\
\hline & $\mathrm{H}$ & ind. $\mathrm{km}^{-2}$ & Population density \\
\hline & $\mathrm{TN}_{\text {sew }}$ & $\mathrm{kg} \mathrm{N} \mathrm{km}^{-2} \mathrm{yr}^{-1}$ & Total $\mathrm{N}$ input into rivers from point sources \\
\hline \multirow[t]{8}{*}{ Diffuse sources } & $\mathrm{TN}_{\mathrm{fe}}$ & $\mathrm{kg} \mathrm{N} \mathrm{km}^{-2} \mathrm{yr}^{-1}$ & TN applied as fertilizer \\
\hline & $\mathrm{TN}_{\mathrm{ma}}$ & $\mathrm{kg} \mathrm{N} \mathrm{km}^{-2} \mathrm{yr}^{-1}$ & TN excreted as manure \\
\hline & $\mathrm{TN}_{\exp }$ & $\mathrm{kg} \mathrm{N} \mathrm{km}^{-2} \mathrm{yr}^{-1}$ & TN exported from the watershed as crop harvest \\
\hline & $\mathrm{TN}_{\mathrm{fix}}$ & $\mathrm{kg} \mathrm{N} \mathrm{km}^{-2} \mathrm{yr}^{-1}$ & TN fixed by natural and agricultural fixation \\
\hline & $\mathrm{TN}_{\mathrm{dep}}$ & $\mathrm{kg} \mathrm{N} \mathrm{km}^{-2} \mathrm{yr}^{-1}$ & TN deposited via atmospheric deposition $\left(\mathrm{NO}_{y}+\mathrm{NH}_{x} \text {, wet }+ \text { dry }\right)^{\mathrm{a}}$; for each drainage area \\
\hline & $\mathrm{FE}_{\text {riv }}$ & $0-1$ & Fraction of DIN input to rivers not retained within the river system, and exported to the mouth \\
\hline & $\mathrm{FE}_{\mathrm{ws}}$ & $0-1$ & Fraction of $\mathrm{N}$ exported from landscape to rivers as DIN \\
\hline & $e$ & $0-1$ & Watershed export coefficient \\
\hline
\end{tabular}

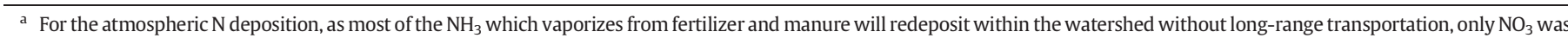
counted in the present study. 
DIN in sewage effluent without treatment, and 0.255 is the maximum increase in DIN to TN ratio that can be achieved by sewage treatment (Seitzinger, 1995).

\subsubsection{Diffuse sources $\left(T N_{\text {diff }}\right)$}

The net amount of diffuse source $\mathrm{N}$ input $\left(\mathrm{TN}_{\text {diff }}\right)$ was estimated as shown in Eq. (4).

$\mathrm{TN}_{\mathrm{diff}}=\mathrm{TN}_{\mathrm{fe}}+\mathrm{TN}_{\mathrm{ma}}+\mathrm{TN}_{\mathrm{fix}}+\mathrm{TN}_{\mathrm{dep}}-\mathrm{TN}_{\mathrm{exp}}$

where $\mathrm{TN}_{\mathrm{fe}}$ refers to yearly $\mathrm{N}$ fertilizer application in the watershed area; $\mathrm{TN}_{\mathrm{ma}}$ refers to total manure $\mathrm{N}$ input (animal manure and human excretion in rural areas); $\mathrm{TN}_{\text {fix }}$ refers to the sum of $\mathrm{N}$ fixation from both anthropogenic and natural sources; $\mathrm{TN}_{\mathrm{dep}}$ refers to atmospheric $\mathrm{N}$ deposition (including dry and wet deposition); $\mathrm{TN}_{\exp }$ refers to total $\mathrm{N}$ in crops that is removed from the land by harvest. All terms are in $\mathrm{kg} \mathrm{N} \mathrm{km}{ }^{-2} \mathrm{yr}^{-1}$.

Data for single and compound $\mathrm{N}$ chemical fertilizer application were available by county in the statistical yearbooks from 1980 to 2010. The data for all $\mathrm{N}$ fertilizer forms were converted into elemental $\mathrm{N}$ to estimate $\mathrm{N}$ fertilizer input.

Livestock was categorized into four types: pigs, cattle, sheep and poultry. Animal manure $\mathrm{N}$ input was calculated by multiplying yearly animal fattened stock by $\mathrm{N}$ excretion rates (Table 2). Data for marketable fattened stock of each type of livestock were also available by county in the statistical yearbooks from 1980 to 2010. Given the fact that human excretion in rural areas of China is discharged without treatment and is thus an important diffuse $\mathrm{N}$ source to watersheds, rural human excretion was added into total manure and calculated by multiplying yearly rural population by $\mathrm{N}$ excretion rates (Table 2 ).

$\mathrm{N}$ fixation involves symbiotic and non-symbiotic $\mathrm{N}$ fixation by crops and forests. $\mathrm{N}$ fixation was estimated by multiplying planting area by the relevant $\mathrm{N}$-fixation rates for each crop and forest type. Data on the planting area of each crop were collected from statistical yearbooks from 1980 to 2010, and the areas of forest land in both watersheds were extracted from GIS maps of land cover category in 1986, 1996, 2002 and 2007 and linearly interpolated to other years. The N fixation rates for each crop and forest type are listed in Table 3.

Total atmospheric $\mathrm{N}$ deposition rates over major counties in the Jiulong River watershed for the year 2004 have been monitored by Chen et al. (2008), and N deposition from 1990 to 2009 in Xiamen city (adjacent to the watershed) has been estimated by Chen et al. (2011). Total atmospheric $\mathrm{N}$ deposition rates in Xiamen city in other years were estimated using the relationship between total $\mathrm{N}$ deposition rate and DIN concentrations in deposition found in 1990-2009. Therefore, atmospheric $\mathrm{N}$ deposition over the Jiulong River watershed in each year was roughly estimated using the monitored $\mathrm{NO}_{3}-\mathrm{N}$ deposition (2004) ratio of each county to Xiamen city. With short lifetime in the atmosphere (1-5 days or less for $\mathrm{NH}_{3}$ ), most of the $\mathrm{NH}_{3}$ emitted from fertilizer and manure is likely to be deposited near to and downwind of its source in medium or large watersheds (Aneja et al., 2001; Warneck, 1988). Given the similar characteristics of the adjacent watersheds (agriculture predominated), net transport of $\mathrm{NH}_{3}$ beyond the Jiulong River watershed boundary was assumed to be small. Therefore,

Table 2

Excretion rates by species category.

\begin{tabular}{llllllll}
\hline Item & $\begin{array}{l}\text { Cattle } \\
\text { feces }\end{array}$ & $\begin{array}{l}\text { Cattle } \\
\text { urine }\end{array}$ & $\begin{array}{l}\text { Pigs } \\
\text { feces }\end{array}$ & $\begin{array}{l}\text { Pigs } \\
\text { urine }\end{array}$ & $\begin{array}{l}\text { Sheep } \\
\text { feces }\end{array}$ & $\begin{array}{l}\text { Poultry } \\
\text { feces }\end{array}$ & $\begin{array}{l}\text { Human } \\
\text { excretion }\end{array}$ \\
\hline $\begin{array}{c}\text { TN content } \\
\left(\mathrm{kg} \mathrm{N} \mathrm{ind}^{-1} \mathrm{yr}^{-1}\right)\end{array}$ & 31.9 & 29.2 & 2.34 & 2.17 & 2.28 & 0.275 & $3.76(4.23)$ \\
\hline
\end{tabular}

Data source: National Survey of Scaled Livestock and Poultry Pollution and Its Prevention Countermeasure. State Environmental Protection Administration. 2002. Human excretion (4.23 for rural areas in Longyan and Zhangzhou) derived from the National Pollution Census Office, China (http://cpsc.mep.gov.cn/).
Table 3

Fixation $\mathrm{N}$ rates for crops and forest.

\begin{tabular}{llll}
\hline Items & $\begin{array}{l}\mathrm{N} \text { content } \\
\left(\mathrm{kg} \mathrm{N} \mathrm{hm}^{-2} \mathrm{yr}^{-1}\right)\end{array}$ & Calculation basis & References \\
\hline Peanuts & 86 & Land area & (Barry et al., 1993) \\
Soybean & 78 & Land area & (Barry et al., 1993) \\
Rice & 45 & Land area & (Zhu, 1997) \\
Other crops & 15 & Land area & (Zhu, 1997) \\
Forest & 16 & Land area & (Yan et al., 2003) \\
\hline
\end{tabular}

in estimation of annual atmospheric $\mathrm{N}$ deposition, only $\mathrm{NO}_{3}$ was counted.

Total $\mathrm{N}$ removed from the watershed in harvested crops was calculated by multiplying crop yield by $\mathrm{N}$ content in each crop. Historical data on crop yield were collected from statistical yearbooks from 1980 to 2010. The $\mathrm{N}$ content of each crop was referenced from Chen et al. (2008).

\subsubsection{Watershed retention}

The watershed export fraction $\left(\mathrm{FE}_{\mathrm{ws}}\right)$ is an integrated export coefficient concerning all possible processes of diffuse $\mathrm{N}$ inputs retained during transport to the surface water, and is correlated to annual water runoff as well as N inputs (Caraco and Cole, 1999; Dumont et al., 2005). Therefore, $\mathrm{FE}_{\mathrm{ws}}$ was defined as a function of total diffuse $\mathrm{N}$ input and runoff (Eq. (5)).

$\mathrm{FE}_{\mathrm{ws}}=e \cdot \mathrm{R}$

where $e$ is the watershed export coefficient $(0-1)$ and $\mathrm{R}$ is annual river runoff $\left(\mathrm{m} \mathrm{yr}^{-1}\right)$.

In fact, $\mathrm{FE}_{\mathrm{ws}}$ is dynamic over time under changing $\mathrm{N}$ balance and hydrological conditions (Wang et al., 2014). Applications of the Global-NEWS-DIN model for estimating $\mathrm{FE}_{\mathrm{ws}}$ at global scales are based on a static export coefficient (Dumont et al., 2005; Mayorga et al., 2010), but using a fixed watershed export coefficient without considering the watershed $\mathrm{N}$ balance and hydrology may produce a large bias (Wang et al., 2014; Yan et al., 2010). In this study, we calculated a fitted or

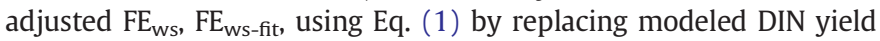
( DIN $\left._{\text {yield-mod }}\right)$ with observed DIN yield ( DIN $\left._{\text {yield-obs }}\right)$. Then the value of $e$ in each year could be obtained by solving Eqs. (5) and (1), as reformulated in Eq. (6). A linear regression between total diffuse $\mathrm{N}$ input $\left(\times 10^{5} \mathrm{~kg} \mathrm{~N} \mathrm{yr}^{-1}\right)$ and $e$ was found in the two watersheds $\left(\mathrm{TN}_{\mathrm{diff}}=1860 e+296.8, \mathrm{R}^{2}=0.88, p<0.01\right.$ for the North River; $\mathrm{TN}_{\mathrm{diff}}=5839 e-253.2, \mathrm{R}^{2}=0.71, p<0.01$ for the West River). Data from extremely wet or dry years were excluded when determining these linear relationships to avoid large deviation. In addition, data from 2008 and 2009 were excluded for verification of the model. Thereafter, regressions were used to calculate modeled $e$ over the study period using yearly total diffuse $\mathrm{N}$ input. The modified model using varying $e$ performed much better than the original model using fixed $e$ (see Section 3.1).

$\frac{\mathrm{FE}_{\mathrm{ws}-\mathrm{fit}}}{\mathrm{R}}=\frac{1}{\mathrm{TN}_{\text {diff }} \cdot \mathrm{R}} \cdot\left(\frac{\mathrm{DIN}_{\text {yield-obs }}}{\mathrm{FE}_{\text {riv }}}-\mathrm{DIN}_{\text {sew }}\right)=e$

\subsubsection{River retention}

Retention of $\mathrm{N}$ within the river system is affected by three major processes: loss by denitrification, retention within constructed reservoirs, and water abstraction (primarily for irrigation and other water consumption) (Dumont et al., 2005; Mayorga et al., 2010). The river export fraction $\left(\mathrm{FE}_{\mathrm{riv}}\right)$ was calculated as the product of the three terms (Eq. (7)) (Mayorga et al., 2010).

$\mathrm{FE}_{\text {riv }}=\left(1-\mathrm{L}_{\mathrm{N}}\right) \cdot\left(1-\mathrm{D}_{\mathrm{N}}\right) \cdot\left(1-\mathrm{Q}_{\mathrm{rem}}\right)$ 
where $L_{N}$ is the retention fraction by denitrification in the river network; $D_{N}$ is the retention fraction in reservoirs; $Q_{\text {rem }}$ is the water removal fraction by consumption. All these terms range from 0 to 1 .

It has been reported that the value of $\mathrm{L}_{\mathrm{N}}$ ranges from 0.20 to 0.76 and is strongly influenced by river watershed size (Behrendt and Opitz, 1999; Dumont et al., 2005; Seitzinger et al., 2002; Soetaert and Herman, 1995). According to an empirical formulation for denitrification loss as a function of watershed area (Dumont et al., 2005), $\mathrm{L}_{\mathrm{N}}$ was estimated to be 0.51 for the North River and 0.45 for the West River. However, test results suggested that the modeled DIN yields were generally higher than the observed DIN yields before 1991 and after 2002 in both rivers (see Section 3.1 and Fig. 2b). Water residence time and $\mathrm{N}$ loading are two important factors influencing the rates of denitrification in a river system (Seitzinger et al., 2006). Long water residence time may facilitate $\mathrm{N}$ removal capacity through denitrification while denitrification effectiveness may decline in hyper-N rich rivers (Chen et al., 2014; Mulholland et al., 2008; Seitzinger et al., 2006; Seitzinger et al., 2002). Direct measurement of excess dissolved $\mathrm{N}_{2}\left(\Delta \mathrm{N}_{2}\right.$, denitrification product) and estimation of area-weighted $\mathrm{N}_{2}$ emission flux in the Jiulong River network during 2010-2011 suggest that gaseous $\mathrm{N}$ removal accounts for 25\% (North River) and 21\% (West River) of riverine N export (Chen et al., 2014). However, considering the short water residence time and shallow water depth compared to larger rivers, we set $\mathrm{L}_{\mathrm{N}}$ to 0.25 in the North River and 0.21 in the West River for the period 2002-2010. Before 1991, $\mathrm{NO}_{3}-\mathrm{N}$ concentrations were low (around $0.4 \mathrm{mg} \mathrm{L}^{-1}$ ) and denitrification would be constrained, and in the period 2002-2010 fairly high nitrate concentrations $\left(>2.6 \mathrm{mg} \mathrm{L}^{-1}\right)$ would also lower the denitrification effectiveness. The values of $\mathrm{L}_{\mathrm{N}}$ in the period 1992-2001 were therefore estimated to be $40 \%$ higher than in the period 2002-2010 as well as before 1991. The modified $\mathrm{L}_{\mathrm{N}}$ here falls in the range of the reported value (Dumont et al., 2005). Using modified $\mathrm{L}_{\mathrm{N}}$ and varying $e$, model results match observations better than the original model using a fixed $\mathrm{L}_{\mathrm{N}}$ (see Section 3.1 and Fig. 3).

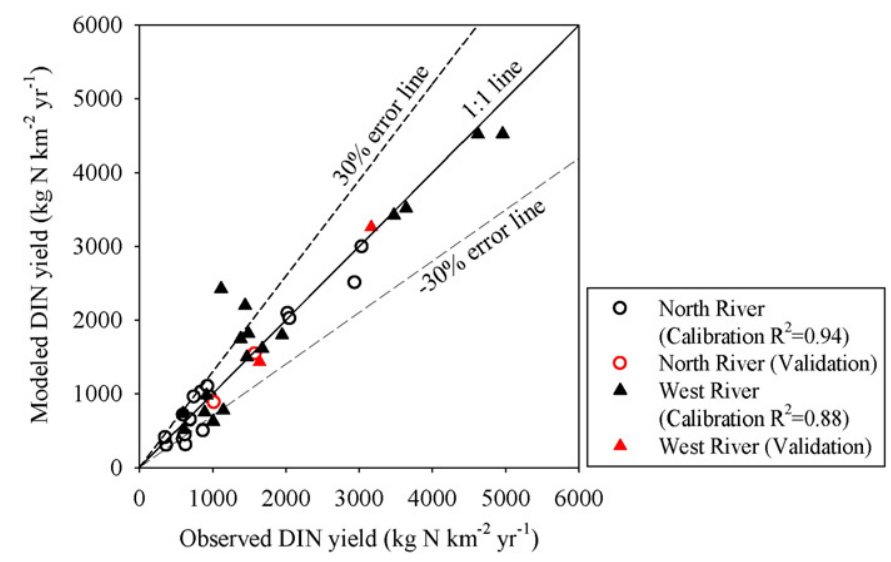

Fig. 3. Modeled versus observed river DIN yields in 1985-2010.

$\mathrm{D}_{\mathrm{N}}$ is estimated as a function of reservoir characteristics (Eq. (8)) (Dumont et al., 2005; Mayorga et al., 2010).

$\mathrm{D}_{\mathrm{N}}=\frac{1}{\mathrm{Q}} \sum_{\mathrm{i}=1}^{n} 0.8845 \cdot\left(\frac{\mathrm{Dept}_{\mathrm{i}}}{\mathrm{Rt}_{\mathrm{i}}}\right)^{-0.3677} \cdot \mathrm{Q}_{\mathrm{i}}$

where $\operatorname{Dept}_{\mathrm{i}}(\mathrm{m})$ is reservoir depth; $\mathrm{Rt}_{\mathrm{i}}$ (years) is water residence time; $\mathrm{i}$ is the reservoir identification number within a watershed $(\mathrm{i}=$ $1,2, \ldots, \mathrm{n}) ; \mathrm{Q}_{\mathrm{i}}\left(\mathrm{km}^{3} \mathrm{yr}^{-1}\right)$ is water discharge intercepted by dam $\mathrm{i}$; $\mathrm{Q}$ $\left(\mathrm{km}^{3} \mathrm{yr}^{-1}\right)$ is the total discharge. Artificial reservoirs with individual storage capacity larger than $1 \times 10^{5} \mathrm{~m}^{3}$ were included in the study. Values of $D_{N}$ of 57 reservoirs in the North River and 34 reservoirs in the West River were calculated and summed in each year according to their impounding time.

$\mathrm{Q}_{\mathrm{rem}}$ was calculated as the amount of water supply for irrigation, domestic and industrial activities withdrawn from the river divided by the amount of river water resources. Data for water supply and water re- a. original model: fixed $e$

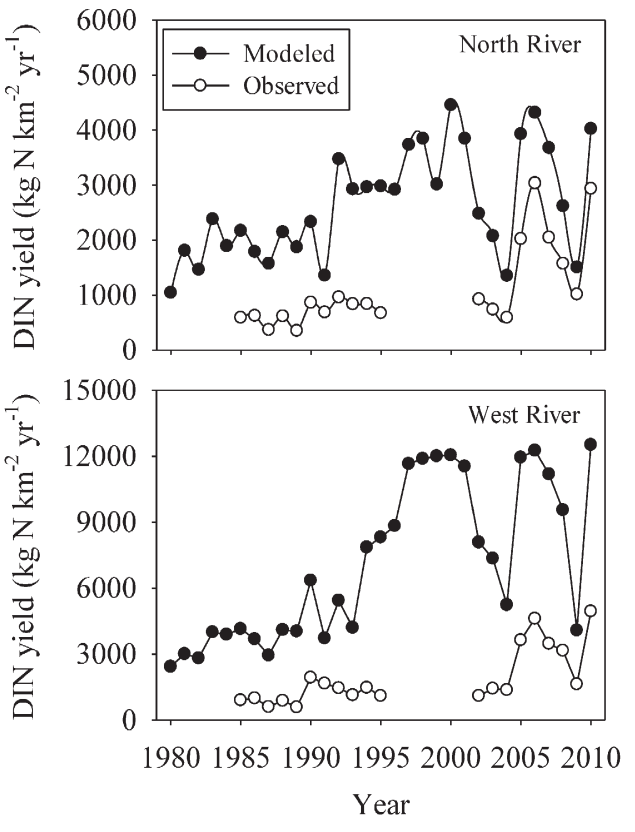

b. modified model: varying $e$
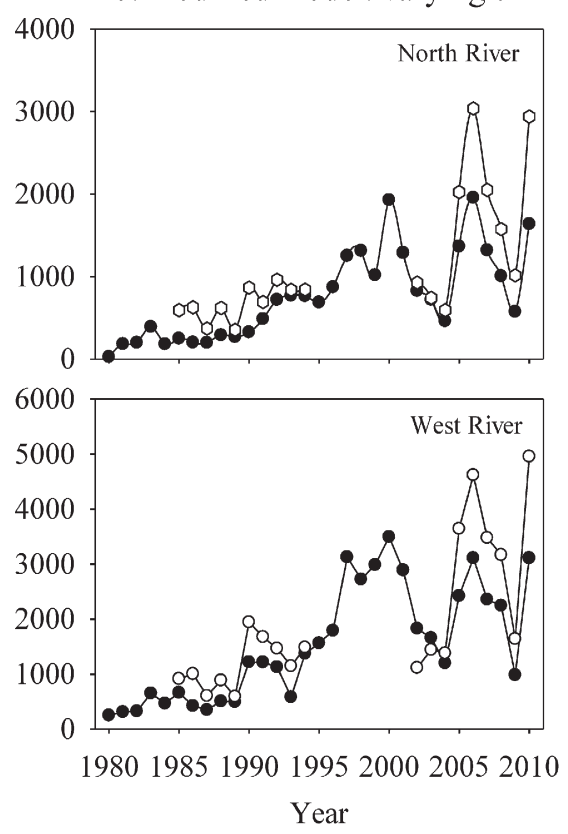

Fig. 2. Comparison of model performance using fixed $e$ versus varying $e$. 
sources were obtained from the Fujian Water Resources Bulletin (www. fjwater.gov.cn).

\subsection{Observed DIN yield}

Observed DIN yield from the North River and the West River was calculated as shown in Eq. (9).

$\mathrm{DIN}_{\text {yield-obs }}=\frac{\mathrm{Q} \cdot \mathrm{C}}{\mathrm{A}}$

where DIN $\mathrm{Dield}_{\text {-obs }}$ is observed DIN yield, $\mathrm{kg} \mathrm{N} \mathrm{km}^{-2} \mathrm{yr}^{-1}$; Q is annual discharge, $\mathrm{km}^{3} \mathrm{yr}^{-1} ; \mathrm{C}$ is observed DIN concentration, $\mathrm{mg} \mathrm{N} \mathrm{L}^{-1} ; \mathrm{A}$ is watershed area, $\mathrm{km}^{2}$. Water quality data is available for 1985-2010 with the exception of 1996-2001, when nitrate was not included in the environmental monitoring program.

\subsection{Scenario analysis}

Previous works applied the Global NEWS models to estimate the future trajectory of nutrient inputs into land and export to the coast for 2030 and 2050 under the Millennium Ecosystem Assessment (MEA) scenarios (Mayorga et al., 2010; Qu and Kroeze, 2010; Seitzinger et al., 2010; Yan et al., 2010). However, decision makers are more concerned with how water quality (nutrient concentration) responds to the reduction of nutrient input. We therefore set eight possible $\mathrm{N}$ input scenarios to examine the change of DIN yields in the two rivers. DIN concentrations were then back calculated by solving Eq. (9), given a range of river runoff levels (dry, normal, and wet year). Total $\mathrm{N}$ inputs from three anthropogenic sources (sewage, chemical fertilizer and manure) were assumed to vary by $+20 \%,+10 \%, 0 \%,-10 \%,-20 \%,-30 \%$, $-40 \%$ and $-50 \%$ relative to the current level (averaged $\mathrm{N}$ input of 2005-2010). All scenarios were simulated under three hydrological conditions (normal year with mean runoff $\left(\mathrm{R}, \mathrm{m} \mathrm{yr}^{-1}\right)$, wet year with high runoff and dry year with low runoff). For each scenario, the watershed export fraction $\left(\mathrm{FE}_{\mathrm{ws}}\right)$ was determined by the relationship with total diffuse $\mathrm{N}$ input and given runoff, while the river export fraction $\left(\mathrm{FE}_{\mathrm{riv}}\right)$ did not change. This scenario analysis will help to set reduction goals for $\mathrm{N}$ inputs to meet national water quality criteria and mitigate eutrophication as well.

\section{Model results}

\subsection{Comparison of original and modified model performance}

The performance of the original model and the modified model using varying $e$ and modified $\mathrm{L}_{\mathrm{N}}$ was first compared. In the original model, the watershed export coefficient $(e)$ was set to 0.94 based on a global calibration (Mayorga et al., 2010) and river network retention $\mathrm{L}_{\mathrm{N}}$ was set to 0.51 for the North River and 0.46 for the West River according to the function of watershed area (Dumont et al., 2005). Unsurprisingly, the original model significantly over-estimated the DIN yields in both rivers (Fig. 2a). The highest difference between modeled and observed DIN yields reached $427 \%$ for the North River and $651 \%$ for the West River, indicating that a fixed $e$ value of 0.94 was unsuitable for the Jiulong River watershed. In the modified model, $e$ was considered as a dependent variable (see description in Section 2.3.3) and varied from 0.02-0.34 for the North River and $0.09-0.22$ for the West River. Using modified $e$, modeled DIN yields closely matched the observed DIN yields (Fig. 2b), and the predictive ability of the modified model was acceptable (Fig. 3). The model performance of the North River was slightly better than the West River, explaining $94 \%$ and $88 \%$ respectively of the observed river DIN yield. However, modeled DIN yields were generally lower than the observed DIN yields before 1991 and after 2002 in both rivers (Fig. 2b). As mentioned in Section 2.3.4, we used a changed $L_{N}$ instead of a fixed value to estimate the DIN yield. Using the modified model with varying $e$ and changed $\mathrm{L}_{\mathrm{N}}$ over the study period, model errors in calibration were mostly less than $30 \%$ (Fig. 3). Model errors in validation (years 2008-2009) were less than $25 \%$ for the North River and less than 15\% for the West River. Given the fact that water quality monitoring programs sometimes also produce uncertainty, the modified model was considered to be acceptable to quantify the longterm trend of DIN export from watershed to coast.

\subsection{Sewage point $N$ input}

Point $\mathrm{N}$ inputs from sewage are dependent on socio-economic development, population growth and sewage treatment. As shown in Fig. 4, GDP per capita in both watersheds began to increase rapidly in the early 1990s while the population grew gradually. Accordingly, total $\mathrm{N}$ inputs from sewage systems per watershed area increased from 53 to $215 \mathrm{~kg} \mathrm{~N} \mathrm{~km}^{-2} \mathrm{yr}^{-1}$ in the North River and from 117 to $392 \mathrm{~kg} \mathrm{~N} \mathrm{~km}^{-2} \mathrm{yr}^{-1}$ in the West River during 1980-2010. Although the North River had a higher GDP per capita, the West River had a much higher urban population density, which resulted in a larger sewage point $\mathrm{N}$ input $\left(253 \pm 83 \mathrm{~kg} \mathrm{~N} \mathrm{~km}^{-2} \mathrm{yr}^{-1}\right)$, about twice as high as the North River $\left(132 \pm 55 \mathrm{~kg} \mathrm{~N} \mathrm{~km}^{-2} \mathrm{yr}^{-1}\right)$.

\subsection{Diffuse $N$ input}

Strong temporal variation of diffuse $\mathrm{N}$ inputs to the watershed was found in 1980-2010, but the turning point differed in the two watersheds (Fig. 5). Total diffuse $\mathrm{N}$ ( $\mathrm{TN}_{\mathrm{diff}}$, net input of all terms) in the North River watershed began to increase in the early 1990s, ranging from 345 to $932 \times 10^{5} \mathrm{~kg} \mathrm{~N} \mathrm{yr}^{-1}$ (Fig. 5a). For the West River, $\mathrm{TN}_{\text {diff }}$ rose dramatically between 1993 and 1999 and kept stable since 2000, with a largest quantity of $1051 \times 10^{5} \mathrm{~kg} \mathrm{~N} \mathrm{yr}^{-1}$ (Fig. 5b). On average, $\mathrm{TN}_{\text {diff }}$ of the West River watershed was $45 \%$ lower than in the North River before 1995 , but thereafter exceeded it by $6 \%$. Temporal trends of $\mathrm{TN}_{\text {diff }}$ almost followed the fertilizer $\mathrm{N}$ input for both rivers (Fig. 5). Before 1990, averaged fertilizer $\mathrm{N}$ input was virtually equivalent in the North River watershed $\left(225 \times 10^{5} \mathrm{~kg} \mathrm{~N} \mathrm{yr}^{-1}\right)$ and West River watershed $\left(217 \times 10^{5} \mathrm{~kg} \mathrm{~N} \mathrm{yr}^{-1}\right)$, but after 1995 , the fertilizer input increased to $513-878 \times 10^{5} \mathrm{~kg} \mathrm{~N} \mathrm{yr}^{-1}$ in the West River, compared with $475-597 \times 10^{5} \mathrm{~kg} \mathrm{~N} \mathrm{yr}^{-1}$ in the North River.

Manure $\mathrm{N}$ inputs to the North River watershed increased from an average of $56 \times 10^{5} \mathrm{~kg} \mathrm{~N} \mathrm{yr}^{-1}$ in the 1980 s to $207 \times 10^{5} \mathrm{~kg} \mathrm{~N} \mathrm{yr}^{-1}$ in 2010 (Fig. 5). The manure $\mathrm{N}$ inputs to the West River watershed also increased in the last decade, with a largest value of $123 \times 10^{5} \mathrm{~kg} \mathrm{~N} \mathrm{yr}^{-1}$. $\mathrm{N}$ fixation shared a small fraction (8\%-10\%) of total input in both watersheds and changed little over time (Fig. 5). The input through $\mathrm{N}$ fixation to the North River watershed ranged from 140 to $163 \times 10^{5} \mathrm{~kg} \mathrm{~N} \mathrm{yr}^{-1}$, twice as large as to the West River (64$75 \times 10^{5} \mathrm{~kg} \mathrm{~N} \mathrm{yr}^{-1}$ ). The amount of atmospheric $\mathrm{N}$ deposition was relatively small compared with other terms. Atmospheric $\mathrm{N}$ deposition in the two watersheds ranged from 3 to $95 \times 10^{5} \mathrm{~kg} \mathrm{~N} \mathrm{yr}^{-1}$ (Fig. 5). $\mathrm{N}$ in harvest crops which has been subtracted from the sum of all inputs before getting total diffuse $\mathrm{N}\left(\mathrm{TN}_{\mathrm{diff}}\right)$, was $10-40 \times 10^{5} \mathrm{~kg} \mathrm{~N} \mathrm{yr}^{-1}$ in the North River watershed and $9-29 \times 10^{5} \mathrm{~kg} \mathrm{~N} \mathrm{yr}^{-1}$ in the West River watershed.

\subsection{Contributions by sources and tributaries}

Source contribution (the proportion of $\mathrm{N}$ exports from the watershed via the rivers from each source to the total DIN yield) has changed over the past 30 years (Fig. 6). Sewage point $N$ contributed a small proportion (average 5\%) in both rivers. The largest contribution came from fertilizer N, which contributed $49 \%-81 \%$ in the West River, much more than in the North River (20\%-64\%). Human excretion in rural areas discharged as diffuse sources contributed less than $10 \%$ in both rivers, decreasing from $7 \%-10 \%$ in the 1980 s to $3 \%-4 \%$ in the 2000 s. In 

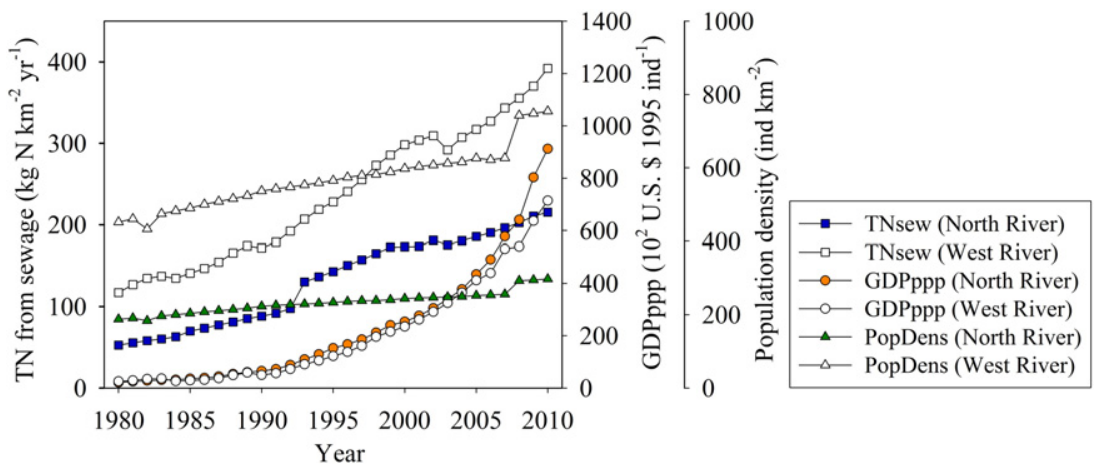

Fig. 4. Sewage N input and socio-economic indicators (GDP and population densities) in the two river watersheds (1980-2010).

the North River, the average contribution of animal manure was $17 \%$ in the 2000s, 4 times more than in the 1980s. In contrast, animal manure contribution in the West River was lower, increasing only slightly from 5\% to 7\% between 1980 and 2010. Total manure N (human + animal) contribution increased from $12 \%$ in 1980 s to $20 \%$ in 2000 s for the North River, while decreased from $13 \%$ in 1980 s to $10 \%$ in 2000 s for the West River. $\mathrm{N}$ fixation was also an important contributor, especially in the early 1980s. In the North River, the contribution of N fixation to total yield reached $32 \%$ before 1990 , of which $80 \%$ was contributed by forest, decreasing to $14 \%-17 \%$ in the late 2000 s. Meanwhile, $N$ fixation contribution in the West River decreased from $25 \%$ to $6 \%$, of which $70 \%$ was contributed by forest. The contributions of atmospheric $\mathrm{N}$ deposition were small (an average of 7\% in the North River and 3\% in the West River) and varied little. In total, three anthropogenic sources (fertilizer, manure and sewage) dominated source contribution, ranging from $61 \%$ in the 1980 s to $78 \%$ in the 2000 s in the North River, and from $76 \%$ in the 1980 s to $92 \%$ in the 2000 s in the West River.

Total amount of exported DIN via the two tributaries to estuary was about $6 \times 10^{3} \mathrm{t} \mathrm{N} \mathrm{yr}^{-1}$ in the $1980 \mathrm{~s}, 20 \times 10^{3} \mathrm{t} \mathrm{N} \mathrm{yr}^{-1}$ in the $1990 \mathrm{~s}$, and $28 \times 10^{3} \mathrm{t} \mathrm{N} \mathrm{yr}^{-1}$ in the 2000s. In the long run, the North River contributed $55 \%$ and the West River contributed $45 \%$ of the total DIN loading to estuary.

\subsection{Observed and modeled river DIN yield}

River discharge fluctuated from 159 to $445 \mathrm{~m}^{3} \mathrm{~s}^{-1}$ in the North River and from 56 to $221 \mathrm{~m}^{3} \mathrm{~s}^{-1}$ in the West River (Fig. 7). Dry years with a very low discharge ( $<45 \%$ of annual mean) occurred in 1991, 2004 and 2009 , while extreme wet years ( $>143 \%$ of annual mean) occurred in 1983, 1992 and 2006. The observed DIN concentration (DIN-obs) in both rivers increased significantly from $0.5-0.6 \mathrm{mg} \mathrm{L}^{-1}$ in the $1980 \mathrm{~s}$ to over $2.5 \mathrm{mg} \mathrm{L}^{-1}$ (North River) and $4.5 \mathrm{mg} \mathrm{L}^{-1}$ (West River) in the 2000s. The West River had a much higher DIN concentration than the North River after 2003, and a relatively high DIN concentration was found in extreme dry years compared to adjacent years. For example, DIN in the North River peaked in $1991\left(1.3 \mathrm{mg} \mathrm{L}^{-1}\right)$. Nevertheless, due to high DIN inputs since 2000, the DIN concentration in two other dry years (2004 and 2009) was insensitive to the extreme hydrological conditions.

Modeled DIN yield ( DIN $_{\text {yield-mod }}$ ) generally increased but fluctuated over the past 30 years (Fig. 7). DIN yields increased 4-5 fold from $337 \mathrm{~kg} \mathrm{~N} \mathrm{~km}^{-2} \mathrm{yr}^{-1}$ in the 1980 s to $1662 \mathrm{~kg} \mathrm{~N} \mathrm{~km}^{-2} \mathrm{yr}^{-1}$ in the 2000s for the North River, and from 653 to $3097 \mathrm{~kg} \mathrm{~N} \mathrm{~km}^{-2} \mathrm{yr}^{-1}$ for the West River. In the last decade, DIN $\mathrm{Dield}_{\text {yied }}$ of the North River fluctuated more dramatically than in the previous period, with the lowest yield in 2004 (916 kg N km${ }^{-2} \mathrm{yr}^{-1}$ ) and 2009 (1262 $\mathrm{kg} \mathrm{N} \mathrm{km}^{-2} \mathrm{yr}^{-1}$ ), ), and the highest yield in 2006 (2823 $\left.\mathrm{kg} \mathrm{N} \mathrm{km}^{-2} \mathrm{yr}^{-1}\right)$ and 2010 (2510 kg N km-2 $\mathrm{yr}^{-1}$ ). Similarly, the West River had the lowest yield of $1743 \mathrm{~kg} \mathrm{~N} \mathrm{~km}^{-2} \mathrm{yr}^{-1}$ and $1430 \mathrm{~kg} \mathrm{~N} \mathrm{~km}^{-2} \mathrm{yr}^{-1}$ in 2004 and 2009 but the highest yield of $4517 \mathrm{~kg} \mathrm{~N} \mathrm{~km}^{-2} \mathrm{yr}^{-1}$ and $4520 \mathrm{~kg} \mathrm{~N} \mathrm{~km}^{-2} \mathrm{yr}^{-1}$ in 2006 and 2010. DIN export from both river systems became more sensitive to shifts in hydrological conditions. In total, river DIN yields showed a significant increasing trend in both rivers, largely controlled by the increasing $\mathrm{N}$ input.

The watershed export ratio (defined as the percentage of river DIN yield to total $\mathrm{N}$ input $\left(\mathrm{DIN}_{\mathrm{sew}}+\mathrm{TN}_{\text {diff }}\right)$, see relative height of black bar and gray bar in Fig. 7) was $7 \%-8 \%$ in the 1980 s but increased to $17 \%$ in the North River and to $13 \%$ in the West River in the 2000s. Moreover, the wet years had higher watershed export ratios than the dry years, especially in recent decade. For example, the watershed export ratio of the North River was as high as 23\% in 2006 and 25\% in 2010, far greater than the export ratio in dry years ( $9 \%$ in 2004 and 13\% in 2009). This indicates a greater storage of nutrients in the land during dry years, and a greater export of the stored nutrients in the following years when rainfall and

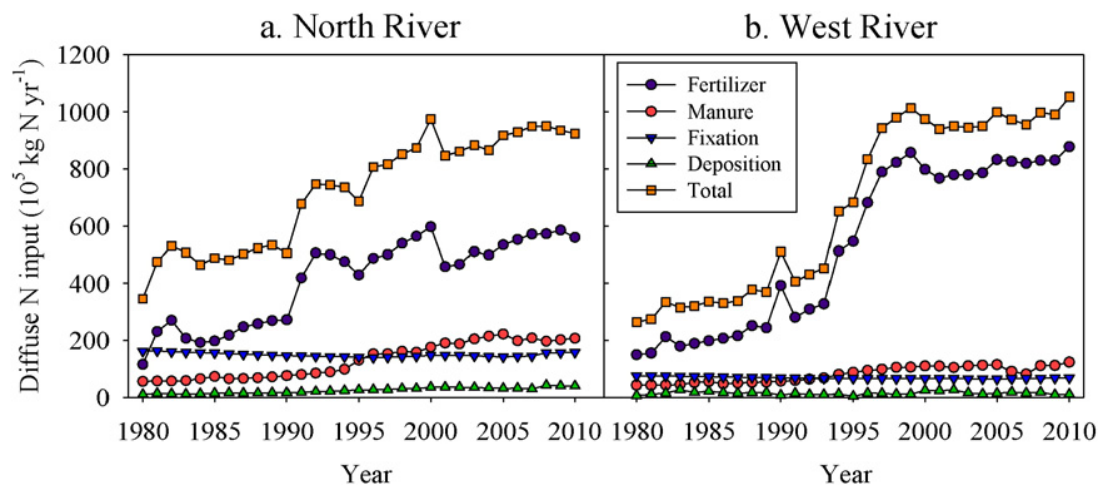

Fig. 5. Diffuse N input to the watershed from various sources (1980-2010). Total input equals to sum of various N inputs minus N exported from the watershed as crop harvest. 


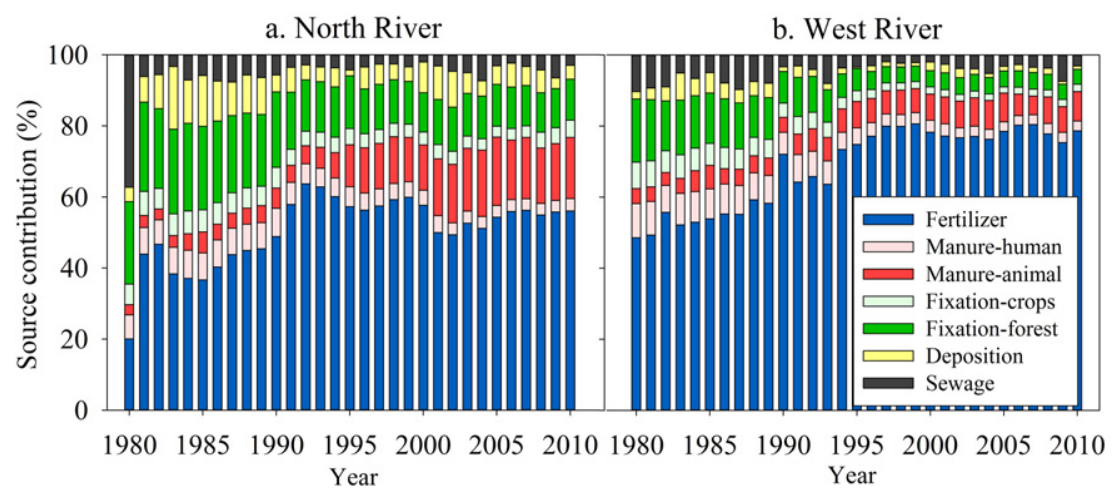

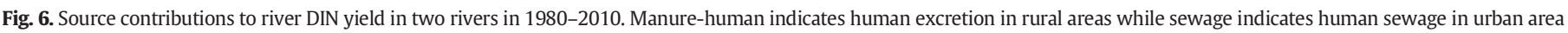
discharging as point source.

discharge were higher, as has been discussed in a previous analysis (Chen and Hong, 2012).

\subsection{Future trend in river DIN yields and concentrations under alternative scenarios}

The projected river DIN yields and back calculated DIN concentrations changed under the different anthropogenic $\mathrm{N}$ input scenarios (Fig. 8). Increasing anthropogenic $\mathrm{N}$ input by $20 \%$ under normal hydrological conditions increased DIN yield from 1986 to $2854 \mathrm{~kg} \mathrm{~N} \mathrm{~km}^{-2} \mathrm{yr}^{-1}$ in the North River and from 3888 to $5301 \mathrm{~kg} \mathrm{~N} \mathrm{~km}^{-2} \mathrm{yr}^{-1}$ in the West River. Cutting 30\% of anthropogenic $\mathrm{N}$ input under normal hydrological conditions decreased the DIN yield in the North River to less than $1000 \mathrm{~kg} \mathrm{~N} \mathrm{~km}^{-2} \mathrm{yr}^{-1}$ and DIN
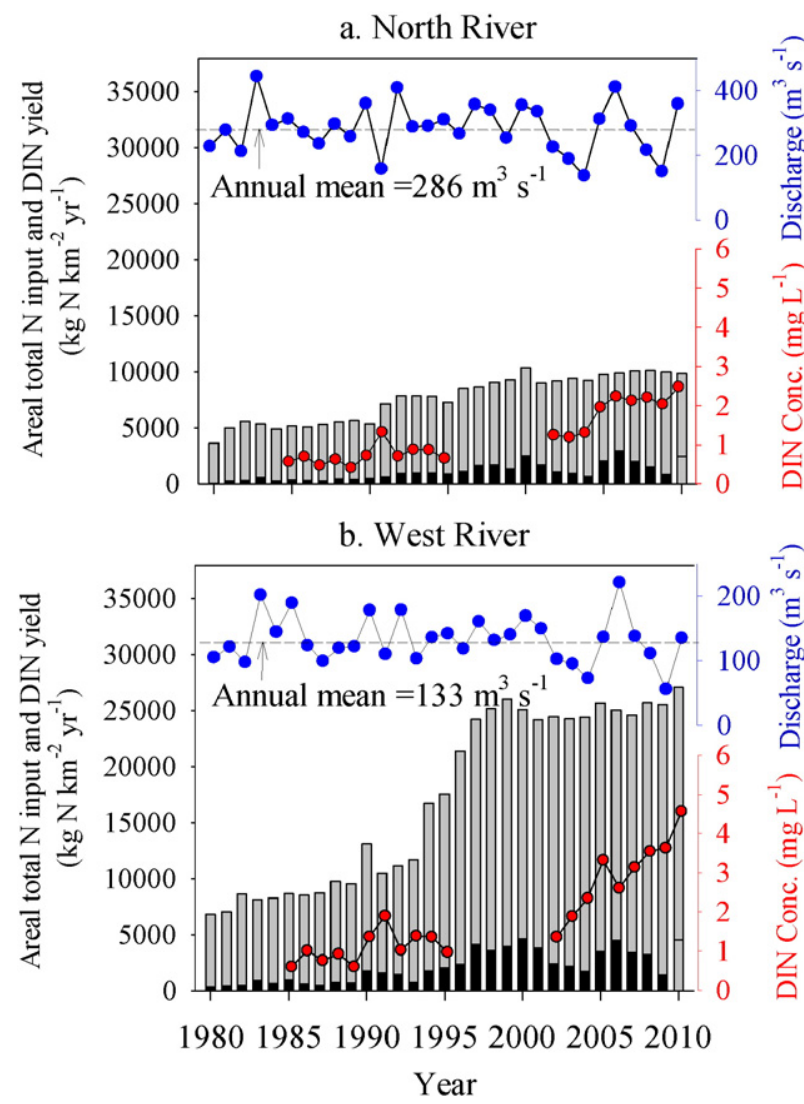

Fig. 7. River discharge, DIN concentration, total N input, and modeled DIN yield in 19802010. Total height of bar indicates total $\mathrm{N}$ input, while black bars refer to modeled DIN yield. concentration decreased to around $1.0 \mathrm{mg} \mathrm{L}^{-1}$. However, for the West River, only by cutting $50 \%$ of anthropogenic N input under normal hydrological conditions could the DIN yield be decreased to $1295 \mathrm{~kg} \mathrm{~N} \mathrm{~km}^{-2} \mathrm{yr}^{-1}$ and DIN concentration to around $1.2 \mathrm{mg} \mathrm{L}^{-1}$. In contrast to normal years, the DIN yield in wet years increased by $26 \%$ for the North River and 35\% for the West River, while the DIN yield in dry years decreased by $45 \%$ for the North River and $42 \%$ for the West River.

\section{Discussion}

4.1. Main drivers and source of increasing nitrogen yield from the watershed to coast

Anthropogenic N, which was a major contributor to riverine DIN yield, changed a lot in magnitude and composition between the 1980s and 2000s (Fig. 9). Human activities significantly modify $\mathrm{N}$ inputs (mainly chemical fertilizer and manure) and $\mathrm{N}$ export in the Jiulong River watershed. It was calculated that the contribution of chemical fertilizer $\mathrm{N}$ to the total DIN yield increased from $40 \%$ in the 1980 s to $54 \%$ in the 2000s in the North River and from 56\% to $78 \%$ in the West River. Land use has changed over the past 30 years due to intensive exploitation. Economic reform policies have resulted in upland forest being transformed to orchards; and arable land change has increased significantly since the late 1980s. In addition, the agricultural structure shifted from traditional crops such as rice and sweet potato to cash crops (e.g. C. maxima, D. longan) since the mid-1990s, resulting in a large increase in fertilizer application rate. At present, the West River has a larger planting area although its catchment is only half as large

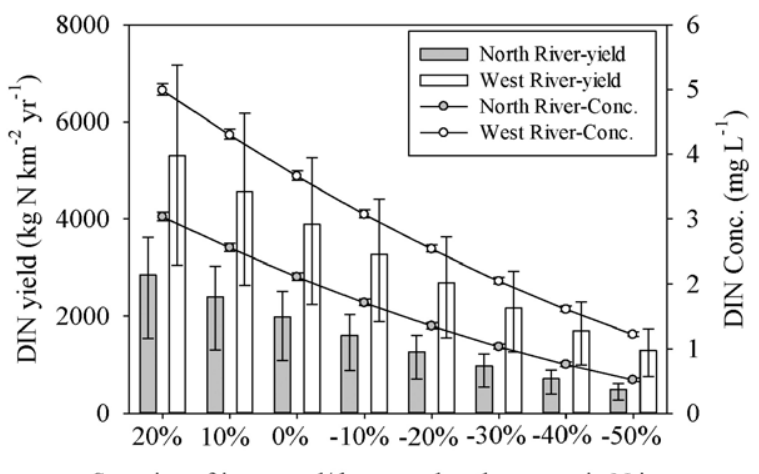

Senarios of increased/decreased anthropogenic $\mathrm{N}$ inputs

Fig. 8. Projected areal DIN yields (bar) and back calculated DIN concentrations (line) under alternative scenarios of anthropogenic $\mathrm{N}$ inputs (sewage, manure, fertilizer) and three hydrological conditions. Height of the bar refers to normal condition; positive error line refers to wet condition; negative error line refers to dry condition. Scenario $0 \%$ indicates current level (mean N input of 2005-2010). 

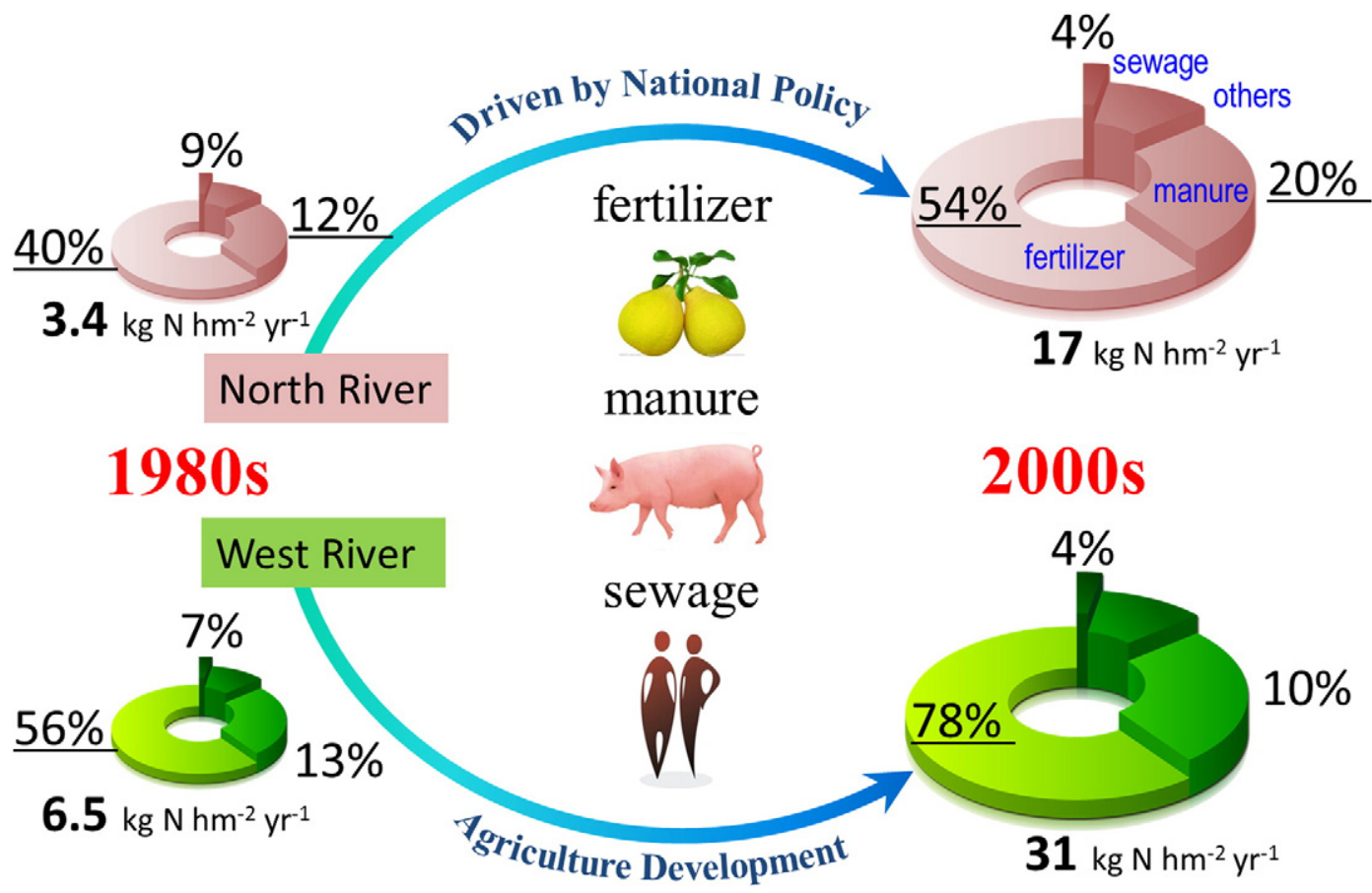

Fig. 9. Exported $\mathrm{N}$ by source and relative contributions of two rivers by comparing 1980 s and 2000s. Others contain nitrogen fixation and atmospheric deposition.

as the North River catchment; therefore West River areal fertilizer input to watershed $\left(20,499 \mathrm{~kg} \mathrm{~N} \mathrm{~km}^{-2} \mathrm{yr}^{-1}\right)$ was four times larger than the North River ( $5594 \mathrm{~kg} \mathrm{~N} \mathrm{~km}^{-2} \mathrm{yr}^{-1}$ ) in the 2000s. A N budget developed for the Jiulong River watershed for the year 2004 suggests that fertilizer contributed $67 \%$ of total input to the catchment (Chen et al., 2008). Over-fertilization has resulted in increased $\mathrm{N}$ losses via runoff, largely due to low $\mathrm{N}$-use efficiency and poor management (Chen and Hong, 2011; Chen et al., 2013).

Due to the presence of large hilly areas there is less arable land in the upper North River catchment and widespread crop planting is impossible. Instead, there has been a rapid growth in animal breeding (mainly pigs) since the late 1990s, and the contribution of manure $\mathrm{N}$ (human + animal) to total DIN yield increased from 12\% in the $1980 \mathrm{~s}$ to $20 \%$ in the 2000 s. A previous study on intensive pig farms suggests a large imbalance between manure discharge and arable land capacity (using manure as fertilizer), resulting in a huge risk of water eutrophication (Zeng et al., 2006). Several algal bloom events have been monitored in the North River (dam reservoirs) since 2009, ascribed to external loading from upper cities and internal cycling (Li et al., 2011). Manure discharge from the growing animal husbandry industry in the Jiulong River watershed has become a critical concern due to the absence of efficient treatment systems for animal wastes. Sewage $\mathrm{N}$ inputs are relatively smaller than the other two diffuse sources of fertilizer and manure $\mathrm{N}$ inputs. However, they have also increased significantly in the past 30 years. Sewage discharge has a strong correlation with economic development and population growth in urban cities. Global sewage emissions have been predicted to increase from $6.4 \mathrm{Tg} \mathrm{N} \mathrm{yr}^{-1}$ in 2000 to $12.0-15.5 \mathrm{Tg} \mathrm{N} \mathrm{yr}^{-1}$ in 2050 (Van Drecht et al., 2009). At present, the population density of the West River is double that of the North River, and the contribution of sewage in the West River was twice as large as in the North River as a result. Driven by the so-called "agricultural to non-agricultural" national policy initiated in the 1980s, two large cities (Longyan and Zhangzhou) and other counties have experienced large-scale rural-to-urban migration and consequent urban sprawl, especially in the past 10 years. Urbanization ratios (urban population divided by total population) have rapidly increased from $18 \%$ to $45 \%$ in the North River watershed and from $20 \%$ to $40 \%$ in the West River watershed. Land-use changes from agricultural to urban built-up area have been observed by remote imaging, and stream nitrate and ammonium concentrations are positively correlated with the percentage of urban area and arable land (Huang et al., 2011). Although sewage and industrial wastewater have been partly treated in Longyan and Zhangzhou since the early 2000s, mainly for reduction of chemical oxygen demand (COD), the amount of nutrient discharged to waterbodies has continued to increase (Chen et al., 2013). In addition to sewage treatment plants, dense residential housing is usually built along the river, resulting in the direct discharge of a large quantity of wastes and an increase in ammonium concentration (Chen et al., 2014).

As a developing country, China relies on agriculture as a primary industry to feed its large population. The Jiulong River watershed is still dominated by agricultural production, although other industries are growing rapidly. Driven by related national reform policies (agriculture structural shift, agricultural to non-agricultural, urbanization), rapid socio-economic development and poor nutrient management are mainly responsible for increasing $\mathrm{N}$ input and river DIN yield. With increasing human activities sand external nutrient loads from watersheds, river water (reservoirs), coastal water (estuary and Xiamen Bay) and aquatic ecosystems have been substantially degraded in the past 30 years. Harmful algal blooms in the estuary and Xiamen Bay have been often reported since 1996 when DIN concentration in the upper estuary increased to over $1.0 \mathrm{mg} \mathrm{L}^{-1}$ (Chen et al., 2013).

\subsection{Processes affecting modeling of nitrogen export and uncertainties}

During calibration of the Global NEWS Model, we found that extreme hydrological conditions might result in over- or underestimation of $\mathrm{N}$ export from the watershed. As Eq. (5) showed, the watershed export fraction $\left(\mathrm{FE}_{\mathrm{ws}}\right)$ is related to coefficient $e$ and runoff. Calibration of $e$ was to develop a relationship between fitted $\mathrm{FE}_{\mathrm{ws}}$ based on observed $\mathrm{N}$ yield and $\mathrm{N}$ input (Eq. (6)). However, for extreme wet years, or years with a dramatic increase in runoff relative to the previous year, $e$ values should be lowered to match observed yield. We assumed that riverine $\mathrm{N}$ was excessively diluted by large storm waters in wetter years compared with normal years. Accordingly, the observed DIN yield would be relatively lower given the same $\mathrm{N}$ input (e). For example, in 1992, 2005 and 2006, modeled DIN yield with calibrated $e$ could be 
over-estimated; therefore, coefficient $e$ was adjusted to a lower value to avoid a large divergence between the modeled and observed yields. On the other hand, in extreme dry years $\mathrm{N}$ accumulates in the system by excessive evaporation. The observed DIN yield could logically be higher, thus the coefficient $e$ should be adjusted to a higher value than the calibrated value, for example in 1991 and 1993. Global climate change is likely to increase the number of heavy storms (Knutson et al., 2010; Webster et al., 2005; Wu et al., 2005), and in the Jiulong River it seems runoff has shown a greater fluctuation in the recent decade (Fig. 7). Therefore, significant changes in hydrological conditions should be considered when simulating and predicting $\mathrm{N}$ export from the watershed in the context of climate change.

Dam construction in the watershed has substantially altered hydrology and biogeochemistry. Dam reservoirs retain more sediment by increasing water residence time, which provides greater opportunity for $\mathrm{N}$ removal processes such as denitrification and ANAMOX (Fan and Shibata, 2015; Mayorga et al., 2010; Salvia-Castellvi et al., 2005). Deep water, lower oxygen and sediment together cause more anaerobic sediment and hence denitrification in dam reservoirs (Seitzinger et al., 2006; Trimmer et al., 2012). The North River has more artificial reservoirs with a larger storage capacity compared with the West River, contributing to a higher gaseous $\mathrm{N}$ removal through denitrification (Chen et al., 2014). Given the minor capacity of reservoirs relative to total river discharge, the retention fractions by reservoirs $\left(D_{N}\right)$ in both rivers are relatively small $(<0.01)$. In general, $\mathrm{N}$ retention by artificial reservoirs is smaller than by lakes. In the Changjiang River, for example, total $\mathrm{N}$ retention by reservoirs varied from 0.13 in the 1970 s to 0.21 in the 2000s, of which $44 \%-88 \%$ were retained by Lake Dongting and Lake Poyang (Yan et al., 2010). However, effects of dams on N export to the coast might still be underestimated because the details of dams (size, shape and depth, etc.) in the Global NEWS model are not well represented.

Uncertainty may originate from input data. For example, this study used an indirect approach to estimate the $\mathrm{N}$ input from sewage point sources. However, previous studies suggested that the indirect approach may underestimate actual $\mathrm{N}$ discharge to rivers in China (Yan et al., 2010). Nevertheless, the dramatic increase of $\mathrm{N}$ input from diffuse sources in the past decade (Fig. 5) resulted in a relatively small contribution by the sewage point sources $\left(\mathrm{TN}_{\text {sew }}\right)$. In describing $\mathrm{N}$ input to US lands by Sobota et al. (2013), there is a high agreement for datasets of fertilizer or atmospheric deposition but other inputs are moderately to very uncertain. Sobota et al. (2013) stated that certainty of source determination can be increased by: (1) enhancing the spatial and temporal resolution of agricultural $\mathrm{N}$ input data, (2) improving livestock and human waste monitoring, and ( 3 ) better quantifying biological $\mathrm{N}$ fixation in non-cultivated ecosystems. Uncertainty may also existed in the observed DIN yield due to the low sampling frequency (monthly for the North River and bimonthly for the West River) in the current water quality monitoring program. This study has addressed these uncertainties carefully in quantifying the $\mathrm{N}$ input and modeling $\mathrm{N}$ export, but more observations are needed to further verify the model in future.

\subsection{Management strategies based on source tracking and scenario analysis}

Current modeled results and scenario analysis suggest that nutrient management should target anthropogenic N inputs (fertilizer, manure and sewage), since these provide a major contribution (61\%-92\%) to river DIN yield. In order to decrease river DIN concentration to around $1.0 \mathrm{mg} \mathrm{L}^{-1}$ and meet national surface water quality criteria, current $\mathrm{N}$ inputs (mainly chemical fertilizer) in the West River should be reduced by $50 \%$ (Fig. 8). For the North River, a reduction of $30 \%$ of anthropogenic $\mathrm{N}$ inputs (with emphasis on fertilization control and manure treatment) will be required to meet the criteria for a drinking water source (total $\mathrm{N}$ less than $1.0 \mathrm{mg} \mathrm{L}^{-1}$ ) (Fig. 8). Therefore, we recommend that the current $\mathrm{N}$ inputs in the two main tributaries should be at least reduced by $30 \%$ in the North River and 50\% in the West River, which is equivalent to abating 60\% of total DIN loading to the estuary. In this scenario, total river $\mathrm{N}$ loading to estuary (sum of two tributaries) of $14 \times 10^{3} \mathrm{t} \mathrm{N} \mathrm{yr}^{-1}$ will be necessary to reduce the level to that of the early $1990 \mathrm{~s}\left(11-15 \times 10^{3} \mathrm{t} \mathrm{N} \mathrm{yr}^{-1}\right)$ when no harmful algal bloom events were recorded. In this case, the long-term goal of improving water quality and mitigating eutrophication in both river and coastal water is expected to be achieved.

DIN yields in the West River were much higher than in the North River, which means the West River watershed is under more stress from human activities. However, this also implies that nutrient management in the West River might be more cost effective compared with the North River. Mitigating eutrophication of the aquatic ecosystem requires watershed-wide nutrient abatement (Chen et al., 2013; Smith, 2006). Critical source areas have been identified. Here we have highlighted the need for an integrated management of anthropogenic sources from watershed to coast (Chen and Hong, 2012). Further optimization of selected measures is necessary to minimize costs (investment) given the varied effectiveness of nutrient reduction measures (Kong et al., 2015). In addition, extreme weather events (drought and floods) have a large influence on riverine nutrient export to coast (Chen et al., 2012; Chen et al., 2015). Therefore, nutrient pollution controls should take future climate change into consideration.

\section{Acknowledgments}

This study was supported by the National Natural Science Foundation of China (No. 41376082; U1305231), Xiamen Southern Oceanographic Center (14GST68NF32), the Program for New Century Excellent Talents in University (NCET-13-0496), and Fujian Provincial S\&T Project (2013YZ0001-1). We thank Jonathan Vause for his assistance with English editing and the anonymous reviewers for helpful comments and suggestions which improved the manuscript.

\section{References}

Anderson, D.M., Burkholder, J.M., Cochlan, W.P., Glibert, P.M., Gobler, C.J., Heil, C.A., Kudela, R.M., Parsons, M.L., Rensel, J.E.J., Townsend, D.W., Trainer, V.L., Vargo, G.A., 2008. Harmful algal blooms and eutrophication: examining linkages from selected coastal regions of the United States. Harmful Algae 8, 39-53.

Aneja, V.P., Roelle, P.A., Murray, G.C., Southerland, J., Erisman, J.W., Fowler, D., Asman, W.A.H., Patni, N., 2001. Atmospheric nitrogen compounds II: emissions, transport, transformation, deposition and assessment. Atmos. Environ. 35, 1903-1911.

Arnold, J.G., Srinivasan, R., Muttiah, R.S., Williams, J.R., 1998. Large area hydrologic modeling and assessment part I. Jawra. J. Am. Water Resour. Assoc. 34, 73-89.

Barry, D.A.J., Goorahoo, D., Goss, M.J., 1993. Estimation of nitrate concentrations in groundwater using a whole farm nitrogen budget. J. Environ. Qual. 22, 767-775.

Behrendt, H., Opitz, D., 1999. Retention of nutrients in river systems: dependence on specific runoff and hydraulic load. In: Garnier, J., Mouchel, J.-M. (Eds.), Man and River Systems. Springer, Netherlands, pp. 111-122.

Billen, G., Garnier, J., 2007. River basin nutrient delivery to the coastal sea: assessing its potential to sustain new production of non-siliceous algae. Mar. Chem. 106, 148-160.

Bowes, M.J., Hilton, J., Irons, G.P., Hornby, D.D., 2005. The relative contribution of sewage and diffuse phosphorus sources in the River Avon catchment, southern England: implications for nutrient management. Sci. Total Environ. 344, 67-81.

Caraco, N.F., Cole, J.J., 1999. Human impact on nitrate export: an analysis using major world rivers. Ambio 28, 167-170.

Chen, N., Hong, H., 2011. Nitrogen export by surface runoff from a small agricultural watershed in southeast China: seasonal pattern and primary mechanism. Biogeochemistry $106,311-321$.

Chen, N., Hong, H., 2012. Integrated management of nutrients from the watershed to coast in the subtropical region. Curr. Opin. Environ. Sustain. 4, 233-242.

Chen, N., Hong, H., Zhang, L., Cao, W., 2008. Nitrogen sources and exports in an agricultural watershed in southeast China. Biogeochemistry 87, 169-179.

Chen, N., Hong, H., Huang, Q., Wu, J., 2011. Atmospheric nitrogen deposition and its longterm dynamics in a southeast China coastal area. J. Environ. Manag. 92, 1663-1667.

Chen, N., Wu, J., Hong, H., 2012. Effect of storm events on riverine nitrogen dynamics in a subtropical watershed, southeastern China. Sci. Total Environ. 431, 357-365.

Chen, N., Peng, B., Hong, H., Turyaheebwa, N., Cui, S., Mo, X., 2013. Nutrient enrichment and $\mathrm{N}: \mathrm{P}$ ratio decline in a coastal bay-river system in southeast China: the need for a dual nutrient ( $\mathrm{N}$ and $\mathrm{P}$ ) management strategy. Ocean Coast. Manag. 81, 7-13.

Chen, N., Wu, J., Chen, Z., Lu, T., Wang, L., 2014. Spatial-temporal variation of dissolved $\mathrm{N}_{2}$ and denitrification in an agricultural river network, southeast China. Agric. Ecosyst. Environ. 189, 1-10. 
Chen, N., Wu, Y., Chen, Z., Hong, H., 2015. Phosphorus export during storm events from a human perturbed watershed, southeast China: implications for coastal ecology. Estuar. Coast. Shelf Sci.http://dx.doi.org/10.1016/j.ecss.2015.03.023

Davidson, K., Gowen, R.J., Harrison, P.J., Fleming, L.E., Hoagland, P., Moschonas, G., 2014. Anthropogenic nutrients and harmful algae in coastal waters. J. Environ. Manag. 146, 206-216

Dumont, E., Harrison, J.A., Kroeze, C., Bakker, E.J., Seitzinger, S.P., 2005. Global distribution and sources of dissolved inorganic nitrogen export to the coastal zone: results from a spatially explicit, global model. Glob. Biogeochem. Cycles 19, GB4S02.

Fan, M., Shibata, H., 2015. Simulation of watershed hydrology and stream water quality under land use and climate change scenarios in Teshio River watershed, northern Japan. Ecol. Indic. 50, 79-89.

Howarth, R.W., 2008. Coastal nitrogen pollution: a review of sources and trends globally and regionally. Harmful Algae 8, 14-20.

Huang, J., Hong, H., 2010. Comparative study of two models to simulate diffuse nitrogen and phosphorus pollution in a medium-sized watershed, southeast China. Estuar. Coast. Shelf Sci. 86, 387-394.

Huang, J.L., Li, Q.S., Hong, H.S., Lin, J., Qu, M.C., 2011. Preliminary study on linking land use \& landscape pattern and water quality in the Jiulong River watershed. Environ. Sci. 32, 64-72.

Knutson, T.R., McBride, J.L., Chan, J., Emanuel, K., Holland, G., Landsea, C., Held, I., Kossin, J.P., Srivastava, A.K., Sugi, M., 2010. Tropical cyclones and climate change. Nat. Geosci. 3, 157-163.

Kong, H., Lin, H., Peng, B.R., Chen, N.W., LIn, C.C., Fielding, S., 2015. Modelling the costeffective solutions of nitrogen reduction in Jiulong River watershed, China. Estuar. Coast. Shelf Sci.http://dx.doi.org/10.1016/j.ecss.2015.03.001

Li, Y., Cao, W., Su, C., Hong, H., 2011. Nutrient sources and composition of recent algal blooms and eutrophication in the northern Jiulong River, southeast China. Mar. Pollut. Bull. 63, 249-254.

Li, H.M., Tang, H.J., Shi, X.Y., Zhang, C.S., Wang, X.L., 2014. Increased nutrient loads from the Changjiang (Yangtze) River have led to increased harmful algal blooms. Harmful Algae 39, 92-101.

Mayorga, E., Seitzinger, S.P., Harrison, J.A., Dumont, E., Beusen, A.H.W., Bouwman, A.F. Fekete, B.M., Kroeze, C., Van Drecht, G., 2010. Global nutrient export from WaterSheds 2 (NEWS 2): model development and implementation. Environ. Model Softw. 25, 837-853.

Mulholland, P.J., Helton, A.M., Poole, G.C., Hall, R.O., Hamilton, S.K., Peterson, B.J., Tank, J.L., Ashkenas, L.R., Cooper, L.W., Dahm, C.N., Dodds, W.K., Findlay, S.E., Gregory, S.V., Grimm, N.B., Johnson, S.L., McDowell, W.H., Meyer, J.L., Valett, H.M., Webster, J.R. Arango, C.P., Beaulieu, J.J., Bernot, M.J., Burgin, A.J., Crenshaw, C.L., Johnson, L.T., Niederlehner, B.R., O'Brien, J.M., Potter, J.D., Sheibley, R.W., Sobota, D.J., Thomas, S.M., 2008. Stream denitrification across biomes and its response to anthropogenic nitrate loading. Nature 452, 202-205.

Paerl, H.W., Hall, N.S., Calandrino, E.S., 2011. Controlling harmful cyanobacterial blooms in a world experiencing anthropogenic and climatic-induced change. Sci. Total Environ. 409, 1739-1745.

Peñuelas, J., Poulter, B., Sardans, J., Ciais, P., van der Velde, M., Bopp, L., Boucher, O. Godderis, Y., Hinsinger, P., Llusia, J., Nardin, E., Vicca, S., Obersteiner, M., Janssens, I.A., 2013. Human-induced nitrogen-phosphorus imbalances alter natural and managed ecosystems across the globe. Nat. Commun. 4.

Qu, H.J., Kroeze, C., 2010. Past and future trends in nutrients export by rivers to the coastal waters of China. Sci. Total Environ. 408, 2075-2086.

Salvia-Castellvi, M., Iffly, J.F., Borght, P.V., Hoffmann, L., 2005. Dissolved and particulate nutrient export from rural catchments: a case study from Luxembourg. Sci. Total Environ. 344, 51-65.

Sattar, M.A., Kroeze, C., Strokal, M., 2014. The increasing impact of food production on nutrient export by rivers to the Bay of Bengal 1970-2050. Mar. Pollut. Bull. 80, $168-178$.

Seitzinger, S.P., 1995. Data Collection Program in Support of the Harbor-Wide Eutrophication Model for New York-New Jersey Harbor Estuary Program, Report, U.S.

Seitzinger, S., Styles, R., Boyer, E., Alexander, R., Billen, G., Howarth, R., Mayer, B., Van Breemen, N., 2002. Nitrogen retention in rivers: model development and application to watersheds in the northeastern U.S.A. In: Boyer, E., Howarth, R. (Eds.), The Nitrogen Cycle at Regional to Global Scales. Springer, Netherlands, pp. 199-237.

Seitzinger, S., Harrison, J.A., Bohlke, J.K., Bouwman, A.F., Lowrance, R., Peterson, B., Tobias, C., Van Drecht, G., 2006. Denitrification across landscapes and waterscapes: a synthesis. Ecol. Appl. 16, 2064-2090.

Seitzinger, S.P., Mayorga, E., Bouwman, A.F., Kroeze, C., Beusen, A.H.W., Billen, G., Van Drecht, G., Dumont, E., Fekete, B.M., Garnier, J., Harrison, J.A., 2010. Global river nutrient export: a scenario analysis of past and future trends. Glob. Biogeochem. Cycles 24, GB0A08.

Smith, V.H., 2006. Responses of estuarine and coastal marine phytoplankton to nitrogen and phosphorus enrichment. Limnol. Oceanogr. 51, 377-384.

Smith, R.A., Schwarz, G.E., Alexander, R.B., 1997. Regional interpretation of water-quality monitoring data. Water Resour. Res. 33, 2781-2798.

Smith, V.H., Tilman, G.D., Nekola, J.C., 1999. Eutrophication: impacts of excess nutrient inputs on freshwater, marine, and terrestrial ecosystems. Environ. Pollut. 100, 179-196.

Sobota, D.J., Compton, J.E., Harrison, J.A., 2013. Reactive nitrogen inputs to US lands and waterways: how certain are we about sources and fluxes? Front. Ecol. Environ. 11 82-90.

Soetaert, K., Herman, P.J., 1995. Nitrogen dynamics in the Westerschelde estuary (SW Netherlands) estimated by means of the ecosystem model MOSES. Hydrobiologia 311, 225-246.

Strokal, M., Kroeze, C., Li, L., Luan, S., Wang, H., Yang, S., Zhang, Y., 2015. Increasing dissolved nitrogen and phosphorus export by the Pearl River (Zhujiang): a modeling approach at the sub-basin scale to assess effective nutrient management. Biogeochemistry $125,1-22$

Suwarno, D., Lohr, A., Kroeze, C., Widianarko, B., 2013. Past and future trends in nutrient export by 19 rivers to the coastal waters of Indonesia. J. Integr. Environ. Sci. 10, 55-71.

Trimmer, M., Grey, J., Heppell, C.M., Hildrew, A.G., Lansdown, K., Stahl, H., Yvon-Durocher G., 2012. River bed carbon and nitrogen cycling: state of play and some new directions. Sci. Total Environ. 434, 143-158.

Turner, R.E., Rabalais, N.N., 1994. Coastal eutrophication near the Mississippi river delta. Nature 368, 619-621.

Van Drecht, G., Bouwman, A.F., Harrison, J., Knoop, J.M., 2009. Global nitrogen and phosphate in urban wastewater for the period 1970 to 2050. Glob. Biogeochem. Cycles 23 GBOA03.

Wang, J., Li, X., Yan, W., Wang, F., Ma, P., 2014. Watershed nitrogen export model related to changing nitrogen balance and hydrology in the Changjiang River basin. Nutr. Cycl. Agroecosyst. 98, 87-95.

Warneck, P., 1988. Chemistry of the Natural Atmosphere. Academic Press, New York.

Webster, P.J., Holland, G.J., Curry, J.A., Chang, H.R., 2005. Changes in tropical cyclone number, duration, and intensity in a warming environment. Science 309, 1844-1846.

Whitehead, P.G., Wilson, E.J., Butterfield, D., Seed, K., 1998. A semi-distributed integrated flow and nitrogen model for multiple source assessment in catchments (INCA): part II - application to large river basins in south Wales and eastern England. Sci. Total Environ. 210-211, 559-583.

Wu, L.G., Wang, B., Geng, S.Q., 2005. Growing typhoon influence on east Asia. Geophys. Res. Lett. 32, 4.

Yan, W., Zhang, S., Sun, P., Seitzinger, S.P., 2003. How do nitrogen inputs to the Changjiang basin impact the Changjiang River nitrate: a temporal analysis for 1968-1997. Glob. Biogeochem. Cycles 17, 1091.

Yan, W., Mayorga, E., Li, X., Seitzinger, S.P., Bouwman, A.F., 2010. Increasing anthropogenic nitrogen inputs and riverine DIN exports from the Changjiang River basin under changing human pressures. Glob. Biogeochem. Cycles 24.

Yin, K., Harrison, P.J., 2008. Nitrogen over enrichment in subtropical Pearl River estuarine coastal waters: possible causes and consequences. Cont. Shelf Res. 28, 1435-1442.

Zeng, Y., Hong, H.S., Cao, W.Z., Chen, N.W., Wang, W.P., Zhang, L.P., 2006. Evaluation of nitrogen balance on pig/crop farm systems in Jiulong River watershed, China. Aquat. Ecosyst. Health Manag. 9, 21-26.

Zhu, Z.L., 1997. Nitrogen balance and cycling in agroecosystems of China. In: Zhu, Z.L., Wen, Q.X., Freney, J.R. (Eds.), Nitrogen in Soils of China. Springer, Netherlands, pp. 323-338. 